M. Klimczuk-Kochańska, A. Klimczuk, Core-Periphery Model, [in:] S.N. Romaniuk, M. Thapa, P. Marton (eds.), The Palgrave Encyclopedia of Global Security Studies, Palgrave Macmillan, Cham 2019, pp. 1-8, https://doi.org/10.1007/978-3-319-74336-3 320-1.

\title{
Core-Periphery Model
}

Andrzej Klimczuk

Independent Researcher, Bialystok, Poland

Magdalena Klimczuk-Kochańska

Faculty of Management, University of Warsaw, Warsaw, Poland

Keywords: Center-periphery model; Centripetal and centrifugal forces; Regional disparities; Regional polarization

\section{Definition and Introduction}

Core-periphery imbalances and regional disparities figure prominently on the agenda of several disciplines, which result from their enormous impact on economic and social development around the world. In sociology, international relations, and economics, this concept is crucial in explanations of economic exchange. There are few countries that play a dominant role in world trade (sometimes described as the "Global North"), while most countries have a secondary or even a tertiary position in world trade (the "Global South"). Moreover, when we are discussing global, continental, regional, and national economies, we can present regions and even smaller territorial units (such as subregions, provinces, districts, or counties) which have higher wages than some underdeveloped areas within the same larger area in focus.

Such regional inequalities and injustices are the main themes of the core-periphery model, which focuses on tendencies of economic activities to concentrate around some pivotal points. It seeks to explain the spatial inequalities or imbalances observable on all levels or scales by highlighting the role of horizontal and vertical relations between various entities from the level of towns and cities to the global scale. The existence of a core-periphery structure implies that in the spatial dimension (space and place), the socioeconomic development is usually uneven. From such a geographical perspective, the regions known as the "core" are advanced in various areas, while other regions described as the "periphery" serve as social, economic, and political backstages, backyards, and supply sources or - in some cases - are even subject to degradation and decline. Furthermore, the level of development has a negative correlation with distance from the core. The economies of the states that have gone through various stages of development at the earliest and with the fastest pace have become wealthy core regions and growth poles. Those countries and regions where these processes have been slower become or remain the poor periphery. 
M. Klimczuk-Kochańska, A. Klimczuk, Core-Periphery Model, [in:] S.N. Romaniuk, M. Thapa, P. Marton (eds.), The Palgrave Encyclopedia of Global Security Studies, Palgrave Macmillan, Cham 2019, pp. 1-8, https://doi.org/10.1007/978-3-319-74336-3 320-1.

The critical question raised in discussions related to the core-periphery model focuses on the results and outcomes of the disproportions and asymmetry of the relationship and value of various indicators related to the level of regional development. The terms "center" and "core" are often used as synonyms. Peripherality is perceived negatively, and peripheral areas are regions that may generate challenges for the core and may even be deemed to require political interventions from time to time (e.g., regions with a predominantly agricultural structure, regions deprived of natural resources, regions located far from the main transport routes, depopulated regions, and regions where large-scale enterprises have been liquidated resulting in mass unemployment and other social problems). The peripheries are associated with distance, difference, and dependence on external aid and the unfavorable phenomenon of marginalization and deprivation. At the same time, however, there are no uniform or standardized development patterns that could allow solving the issue of the development gap of the underdeveloped and developing countries and regions.

Thus, there have been numerous attempts to identify the factors contributing to uneven development around the world. There is an intense focus on the conflicting relations between centers and peripheries, often reduced to a simple dualism of dominant centers and weak peripheries. This model is of interest to groups such as geographers, scholars of regional studies, town planners, economists, sociologists, as well as practitioners and experts in the field of development studies.

Various theories and policy papers that will be discussed in subsequent sections of this chapter have tried to explain spatial determinants of development. We will first describe the origins of the core-periphery model as may be attributed to Raul Prebisch (1950). Later we will present the human geography approach in the field of regional studies from John Friedmann (1966). Next, attention will be focused on select elements of world-systems theory as proposed by Immanuel Wallerstein (1974). Finally, at the end of the chapter, we discuss recent contributions of mainstream economics from Paul Robin Krugman (1981, 1991, 1998, 2011).

\section{Raul Prebisch's Manifesto (1950)}

The core-periphery concept was developed in the 1950s by Prebisch within the framework of the United Nations Economic Commission for Latin America (ECLA; esp. Comisión Económica para America Latina y el Caribe - CEPAL). Prebisch started using the terminology of "core" and "periphery" already in 1929. In his report for the ECLA titled "The Economic Development of Latin America and its Principal Problems" - often referred to simply as 
M. Klimczuk-Kochańska, A. Klimczuk, Core-Periphery Model, [in:] S.N. Romaniuk, M. Thapa, P. Marton (eds.), The Palgrave Encyclopedia of Global Security Studies, Palgrave Macmillan, Cham 2019, pp. 1-8, https://doi.org/10.1007/978-3-319-74336-3 320-1.

Prebisch's Manifesto - he describes these notions as two broad and contrasting regional categories, that is, the economically developed center and the undeveloped periphery. These terms are connected but also defined by various internal features such as wage levels, production structures, export composition, and other similar attributes.

Prebisch's concept is still often presented in the literature as the foundation of the dependency theory. Prebisch found that productivity increases - wherever they occur - tend to help the manufacturing centers more than the agricultural sectors and areas that are exporting primary goods and resources. Prebisch argued that theories and models stemming from the developed world (the center) were not applicable in the non-developed world (the periphery) due to different situations and historical experiences (Prebisch 1950).

Importantly, the ideas of Prebisch had a tremendous impact on both economic policy and strands of development thinking all over the world. He highlighted that unequal exchange is causing the flow of surplus value from periphery regions to core regions. Prebisch also noted that this issue has been unnoticed for a long time, at least in the social sciences, due to previously used terms and all other variants of the rich-poor dichotomy.

\section{The Core-Periphery Model of Regional Development by John Friedmann (1966)}

The core-periphery model was also of interest to John Friedmann. He further developed this concept in 1966 by underlining the role of spatial distances from the core. His approach is sometimes interpreted and combined with the growth pole theory (focusing on input-output linkages) of Franęois Perroux (1955) as well as with later works of Albert O. Hirschman (1958) who, among others, described the "trickle-down effect" in the theory of unbalanced development. Moreover, it can be noted that Friedmann's model combines elements of the export-based approach presented by Douglass C. North (1955) and parts of Gunnar Myrdal's (1957) theory of cumulative and circular causation with the "spread effect" (whereby development spreads from city to the suburbs and all adjoining areas) and the "backwash effect" (whereby the development of the city tends to gather resources and labor force away from surrounding areas and that may degrade these places).

Friedmann's version of the core-periphery model includes an explanation of why some inner-city areas enjoy considerable prosperity, while others show signs of urban deprivation and poverty, even as urban areas, in general, have some advantage over peripheral rural areas. This model of regional development thus focuses on spatially diversified development. It recognizes the tendency by the most competitive entities to locate their manufacturing and service 
M. Klimczuk-Kochańska, A. Klimczuk, Core-Periphery Model, [in:] S.N. Romaniuk, M. Thapa, P. Marton (eds.), The Palgrave Encyclopedia of Global Security Studies, Palgrave Macmillan, Cham 2019, pp. 1-8, https://doi.org/10.1007/978-3-319-74336-3 320-1.

activities in the most developed regions. Economic centers (cores) dominate over peripheral areas not only in the economic sphere but also in the political and cultural fields. The core, which is usually a metropolitan area, contributes to the development of the periphery even as, at the same time, it is subordinating it in the social and economic dimensions. Centers typically have a high potential for innovation (improvement) and growth, which shapes the geographic diffusion of innovations (Rogers 1962, 2003). At the same time, according to Friedmann, peripheral regions experience lagging growth or even stagnation and may rely on growth driven mainly by the core area's demands for resources.

We should also mention a further division of regions proposed by Friedmann (1966), where core regions and the periphery are divided into "upward transition regions" (advanced or early), "downward transition regions," and "resource frontier regions." Upward transition regions are areas of growth that spread over small centers rather than at the core. Downward transition regions are characterized by depleted resources, low agricultural productivity, or outdated industry. Resource frontier regions are described as the newly "colonized" areas which are brought into production networks for the first time. For example, less accessible inner-city areas may experience a backwash effect with limited investment. The effect is especially well visible when the inner city is close to the newly developing central business district, concentrating a major poverty wealth gap in relatively tight space.

Friedmann's theory is sometimes described similarly to the "three-sector model" (or “Petty's Law") proposed in economics by Allan Fisher, Colin Clark, Jean Fourastie, and Daniel Bell (see review by Ehrig and Staroske 2009). Friedmann's version is called a "core-periphery four-stage model of regional development" that covers the following stages: pre-industrial, transitional, industrial, and postindustrial.

The pre-industrial stage refers to the primary sector (agricultural) of the economy, which is characterized by economic activities limited to a small area and a small-scale settlement structure with small units. Each aspect of pre-industrial society is relatively isolated, small units stay dispersed, and economic entities such as population and traders have low mobility.

The transitional stage is described by the increasing concentration of the economy in the core that is fostered by capital accumulation and industrial growth. A dominant center appears within an urban system and becomes its growth pole. Trade and mobility increase at this stage, but the labor force's space of daily existence is still local because the personal mobility of people stays limited. The periphery is at this point wholly subordinated to the center of political and economic dominance. 
M. Klimczuk-Kochańska, A. Klimczuk, Core-Periphery Model, [in:] S.N. Romaniuk, M. Thapa, P. Marton (eds.), The Palgrave Encyclopedia of Global Security Studies, Palgrave Macmillan, Cham 2019, pp. 1-8, https://doi.org/10.1007/978-3-319-74336-3 320-1.

In the industrial stage, manufacturing (the secondary sector) is growing with increasing employment of people who are migrating from rural areas to urban areas. This change subsequently also results in shifting from using the human workforce to the mechanization and automation of production. Thus, the core-periphery model is also used to describe changes in the labor markets and in the labor economics literature. The model is thus also referred to as "dual labor market theory" and as "insider-outsider theory" (Klimczuk and Klimczuk-Kochańska 2016). In general, both theories assume that labor markets are divided into segments, which are distinguished from each other by a separate system of rules, job requirements, and different skills. For example, human resource policies include a preference (in the primary segment) for recruiting white male workers to managerial positions by offering training, pay gains, promotion, and job security. At the same time, external labor markets are dominated by women and minorities and offer low-paying and low-status jobs. Furthermore, in the industrial stage, through a process of economic growth and diffusion, other growth centers appear. The main reason for deconcentration is the increasing production costs related to labor and land in the core area. This diffusion is linked to increased interactions between elements of the urban system and the construction of transport infrastructure.

The fourth stage, that is, the postindustrial stage, sees a growing demand for workforce in services (the tertiary sector). It is assumed that this stage is characterized by the spatial integration of the economy and the achievement of equilibrium. The urban system becomes fully integrated, and inequalities are reduced significantly. The distribution of economic activities is focused on establishing specializations and a division of labor linked with strong flows along transport corridors. Friedmann believed that the allocation of economic activities should reach optimum, balance, and stability. That does not mean that the trade and mobility of the population should decrease. As far as different areas specialize in specific functions, there will be a division of labor between regions. An integrated model foresees a cyclical movement of the population caused mostly by the age factor: the youth studying in big cities, families settling in the suburbs, and older adults searching for competitive and peaceful rural environments.

To sum up, according to Friedmann's model, the development potential of a given region or country is determined by the stimulating effect of regional growth centers, the construction of infrastructure, and the provision of support from central areas to less developed regions. An advantage of the model is that the assumptions of this theory are also applicable to different spatial scales, that is, from local and regional through to the national and global scale. 
M. Klimczuk-Kochańska, A. Klimczuk, Core-Periphery Model, [in:] S.N. Romaniuk, M. Thapa, P. Marton (eds.), The Palgrave Encyclopedia of Global Security Studies, Palgrave Macmillan, Cham 2019, pp. 1-8, https://doi.org/10.1007/978-3-319-74336-3 320-1.

\section{Core-Periphery Hierarchy in World-Systems Theory by Immanuel Wallerstein (1974)}

The concept of the core-periphery model is also part of Wallerstein's theory, which he proposed in the 1970s to explain the genesis and functioning of capitalism while also seeking to interpret the phenomenon of globalization. This theory assumes that the world-system is a specific spatial and temporal entity, including various political and cultural units that are functioning based on certain specific principles.

An essential element of this theory is the core-periphery hierarchy, whereby discrepancies in interests and inequalities result from the domination of the vibrant center over the weak periphery. Regarding other issues, this theory is quite similar to Prebisch and Friedmann's approaches. In fact, it is often considered as being identical to Prebisch's concept. However, in Wallerstein's theory, center and periphery are inextricably linked together in both material and sociocultural terms. Thus, while dependency theory only suggests that one area is dependent on the other, here neither of the two would function the way it does without the other.

Wallerstein shows that the core regions are innovative and play an active role in international trade, export capital, generate high incomes, and have high productivity and stability of the political system. The core is the site of the exchange of products between the monopolized and free-market zones and the flow of profits to the former. Peripheral areas are less innovative, have low incomes and productivity, are dependent on capital import, have a minor role in international trade, and are politically unstable. Therefore, in this approach, peripheries are rather dependent on the centers and disadvantaged by unequal terms of trade.

Moreover, Wallerstein (1974) distinguishes semi-peripheries that are interpreted as a kind of buffer between the center and the periphery. Even if the semi-peripheral countries and regions experience the highest mobility, their prospective promotion to the status of a core region is decided primarily by international or governmental interventions. Some of the semiperipheries were previously the central areas, while some have advanced from the periphery. In Wallerstein's opinion, the countries of the periphery and the semi-peripheries that build for a comparative advantage on cheap labor stand to lose the investment thus attracted. Labor costs will increase in time on a global scale due to the depletion of the resources of the rural population.

Thomas D. Hall et al. (2011) further extended and modified world-systems theory, e.g., with a view to pre-capitalist societies. The core-periphery differentiation focuses here on diverse sociopolitical groups conducting the active exchange. The peripheries thus have a more 
M. Klimczuk-Kochańska, A. Klimczuk, Core-Periphery Model, [in:] S.N. Romaniuk, M. Thapa, P. Marton (eds.), The Palgrave Encyclopedia of Global Security Studies, Palgrave Macmillan, Cham 2019, pp. 1-8, https://doi.org/10.1007/978-3-319-74336-3 320-1.

significant impact on the center than it is presented in the original concept of the core-periphery hierarchy. Moreover, semi-peripheries are characterized here as zones of innovation.

\section{The Core-Periphery Model in New Economic Geography by Paul Robin Krugman (1991)}

Krugman, a Nobel laureate economist, underlines that it is scandalous that economists have ignored the core-periphery model for so many years (Krugman 1998: 13). He uses some categories and terminology, especially from Wallerstein (Krugman 1981: 149), and combines the idea of the core-periphery model with some assumptions from classical location theories. The first of these theories included Johann Heinrich von Thünen's (1825) model of the dual economy that discusses the city center and its periphery. Some other assumptions come from works of Alfred Marshall $(1879,1890)$ who considered the significance of relations between the development of industrial districts and large local markets. Also, based on the theory of international trade, Krugman thus developed the model of new economic geography.

In Krugman's theory, the increase in income in the core development region is partly at the expense of the peripheral region. It is also essential that globalization processes lead to disproportions in the development between regions and countries and that these disproportions exist because of the progress (deepening) of international integration processes. Standard international exchange models show that market integration can result in losses for a few countries but lead to an increase in the income of most countries involved in the exchange. The central element of the model is the mobility of manufacturing workers observed due to interregional wage differentials. Moreover, companies tend to search for locating their production in the largest markets because it may help them to save on shipping and other combined costs that should be involved if they want to sell at a distance. The size of a market is a result of the number of residents and their income levels. Thus, the crucial indicators refer to the quantity and quality of available jobs. If a more substantial number of manufacturing enterprises concentrate on one of the regions, this will increase the number of jobs and the availability of the goods produced there. As a result, the income of employees in this region increases, which will lead to the migration of other employees to this area. The growing number of employees, and thus consumers, increases the market size that may consume goods produced there. Considering transportation costs, the region concerned thus becomes the most favorable location for enterprises.

New economic geography also describes two different forces: centripetal and centrifugal (Krugman 1991). The centripetal forces are related to agglomeration. Among these, we can find 
M. Klimczuk-Kochańska, A. Klimczuk, Core-Periphery Model, [in:] S.N. Romaniuk, M. Thapa, P. Marton (eds.), The Palgrave Encyclopedia of Global Security Studies, Palgrave Macmillan, Cham 2019, pp. 1-8, https://doi.org/10.1007/978-3-319-74336-3 320-1.

market size, the mobility of workers, and positive external effects. These forces result in a cumulative-circular, divergent, and asymmetric development model in which one region is achieving the core status while the other is becoming periphery. The centrifugal forces are immobile factors, for example, natural resources, competition, and adverse external effects. If either of these forces is dominant, there will be profound interregional differences. Krugman (2011) also considers three factors that can change the relationship between centrifugal and centripetal forces. These are (1) economies of scale in industrial production, (2) transportation costs, and (3) demand for industrial goods. With a view to these forces, it is possible to conceptualize the centripetal governance mechanism of "circular causation" which is described by Krugman as a situation when at the beginning the employees are attracted by the enterprises, but later the same employees who are consumers attract new companies to the region. Krugman convincingly argues that concentration processes are stronger than forces conducive to dispersion. This usually leads to polarization or at least to the creation of distinct variations in the level of socioeconomic development in space. It is worth noting this new trend of thinking that considers the spatial aspects of socioeconomic development. The theory has extensive influence across various fields of study, such as urban and regional studies, international trade, development studies, and industrial organization.

\section{Conclusion}

The spatial inequalities of social-economic development processes result in the emergence of marginalized areas (peripheries) which are mainly rural areas. Peripherality is a complex and multidimensional concept. It has a relative character: the identification and classification of a given area as peripheral one depend on adopted criteria and a reference point. In general, the peripherality assessment is negative and emphasizes traits such as backwardness, dependence, marginalization, and deprivation. States and regions use various mechanisms of public intervention under the slogan of striving for social and territorial cohesion. The effects of these efforts are, however, far from satisfactory.

A review of selected theories and concepts of regional development allows us to indicate various causes of peripherality, although many of the theoretical concepts discussed relate to this only indirectly. The phenomenon of cumulative causation results in the simultaneous occurrence of negative phenomena in impoverished and peripheral areas, whose relations and interconnections lead to permanent exclusion and marginalization. It is challenging to escape such a "path dependence," and it is virtually impossible to accomplish this without outside 
M. Klimczuk-Kochańska, A. Klimczuk, Core-Periphery Model, [in:] S.N. Romaniuk, M. Thapa, P. Marton (eds.), The Palgrave Encyclopedia of Global Security Studies, Palgrave Macmillan, Cham 2019, pp. 1-8, https://doi.org/10.1007/978-3-319-74336-3 320-1.

interference (Magnusson and Ottosson 2009). On the other hand, it should be noted that spatial unevenness is a feature of socioeconomic development, which is an inevitable phenomenon.

The spatial diversity of socioeconomic development, especially in international terms, may also lead to the use of the so-called latecomer advantage or leapfrogging based on the economic benefits resulting from the omission of particular stages of development (Yap and Rasiah 2016). An economically backward entity (e.g., the state) may avoid unfavorable processes and may focus on copying only tested ready-made solutions, without incurring the costs related to the quest to find these solutions (e.g., in terms of technology and innovation).

From a historical perspective, the core-periphery model is related to processes of industrialization and urbanization that deepened the split between core and periphery areas. Regions with attractive geographic and communication locations benefited from industrialization and became core areas that drew in economic entities seeking economies of scale, exerted demand for an increasing amount of labor resources, attracted external capital, and effectively competed for these resources with the periphery. As a result, at the other extreme, peripheral regions were established that have lost the majority of their labor resources and which are not attractive to external capital due to the monofunctional structure of the local economy. Most of the rural areas are in this group, except for those located near large urban centers. Core areas also become clusters of economic activity, sources of innovation, and gatherings of the creators of innovation sometimes described as the "creative class" (Florida 2002, 2017). Excessive costs, especially of introducing technological innovations, are a barrier to their transfer to peripheral regions (Klimczuk and Klimczuk-Kochańska 2015). Costs including financial investments and the training of workers are effectively weakening the effects of diffusion (spread or spillover) of technical progress and knowledge. Insufficient endogenous potential (in terms of human capital and social capital) for absorbing innovation also intensifies adverse economic and social effects in peripheral areas.

Further open discussion on the causes of peripherality is needed as well as more awareness of needs and potential positive responses to related social, economic, and political challenges. The role of global economic organizations such as the G20, the Organisation for Economic Cooperation and Development (OECD), and the World Economic Forum (WEF) may also merit attention in this respect. Most of the intergovernmental organizations concerned claim that they want to reduce global inequalities and resolve problems of poverty, even as they are subject to criticism for policies and decisions that in effect serve to keep the status quo (Held and McGrew 2007). 
M. Klimczuk-Kochańska, A. Klimczuk, Core-Periphery Model, [in:] S.N. Romaniuk, M. Thapa, P. Marton (eds.), The Palgrave Encyclopedia of Global Security Studies, Palgrave Macmillan, Cham 2019, pp. 1-8, https://doi.org/10.1007/978-3-319-74336-3 320-1.

\section{References}

Ehrig, D., \& Staroske, U. (2009). The gap of services and the three-sector-hypothesis (Petty's law): Is this concept out of fashion or a tool to enhance welfare? In D. Harrisson, R. Bourque, \& G. Szell (Eds.), Social innovation, the social economy and world economic development (pp. 261-278). Frankfurt am Main: Peter Lang.

Florida, R. (2002). The rise of the creative class: And how it's transforming work, leisure, community and everyday life. New York: Basic Books.

Florida, R. (2017). The new urban crisis: How our cities are increasing inequality, deepening segregation, and failing the middle class - And what we can do about it. New York: Basic Books.

Friedmann, J. (1966). Regional development policy: A case study of Venezuela. Cambridge: MIT Press.

Hall, T. D., Kardulias, P. N., \& Chase-Dunn, C. (2011). World-systems analysis and archaeology: Continuing the dialogue. Journal of Archaeological Research, 19 (3), 233279.

Held, D., \& McGrew, A. (2007). Globalization/anti-globalization: Beyond the great divide. Cambridge: Polity. Hirschman, A. O. (1958). The strategy of economic development. New Haven: Yale University Press.

Klimczuk, A., \& Klimczuk-Kochańska, M. (2015). Technology transfer. In M. Odekon (Ed.), The SAGE encyclopedia of world poverty (2nd ed., pp. 1529-1531). Los Angeles: SAGE.

Klimczuk, A., \& Klimczuk-Kochańska, M. (2016). Dual labor market. In N. Naples, R. Hoogland, M. Wickramasinghe, \& A. Wong (Eds.), The Wiley-Blackwell encyclopedia of gender and sexuality studies (pp. 1 -3). Hoboken: Wiley-Blackwell.

Krugman, P. (1981). Intraindustry specialization and the gains from trade. Journal of Political Economy, 89(5), 959-973.

Krugman, P. (1991). Increasing returns and economic geography. Journal of Political Economy, 99(3), 483-499.

Krugman, P. (1998). What's new about the new economic geography? Oxford Review of Economic Policy, 14(2), 7-17.

Krugman, P. (2011). The new economic geography, now middle-aged. Regional Studies, 45(1), $1-7$.

Magnusson, L., \& Ottosson, J. (Eds.). (2009). The evolution of path dependence. Cheltenham/Northampton: Edward Elgar. 
M. Klimczuk-Kochańska, A. Klimczuk, Core-Periphery Model, [in:] S.N. Romaniuk, M. Thapa, P. Marton (eds.), The Palgrave Encyclopedia of Global Security Studies, Palgrave Macmillan, Cham 2019, pp. 1-8, https://doi.org/10.1007/978-3-319-74336-3 320-1.

Marshall, A. (1879). The economics of industry. London: Macmillan.

Marshall, A. (1890). Principles of economics. London: Macmillan.

Myrdal, G. (1957). Rich lands and poor: The road to world prosperity. New York: Harper.

North, D. C. (1955). Location theory and regional economic growth. Journal of Political Economy, 63, 243-258.

Perroux, F. (1955). Materiaux pour une analyse de la croissance economique [Materials for an analysis of economic growth]. Paris: ISEA.

Prebisch, R. (1950). The economic development of Latin America and its principal problems. Lake Success: United Nations Department of Economic Affairs.

Rogers, E. M. (1962). Diffusion of innovations (1st ed.). New York: Free Press.

Rogers, E. M. (2003). Diffusion of innovations (5th ed.). New York: Free Press.

von Thünen, J. H. (1825). Der isolirte Staat in Beziehung auf Landwirtschaft und

Nationalokonomie [The isolated state in relation to agriculture and economics].

Hamburg: Friedrich Perthes.

Wallerstein, I. (1974). The rise and future demise of the world capitalist system: Concepts for comparative analysis. Comparative Studies in Society and History, 16 (4), 387-415.

Yap, X.-S., \& Rasiah, R. (2016). Catching up and leapfrogging: The new latecomers in the integrated circuits industry. Abingdon/New York: Routledge.

\section{Further Reading}

Baldwin, R., Forslid, R., Martin, P., Ottaviano, G., \& Robert-Nicoud, F. (2011). Economic geography and public policy. Princeton: Princeton University Press.

Capello, R., \& Nijkamp, P. (Eds.). (2010). Handbook of regional growth and development theories. Cheltenham/Northampton: Edward Elgar.

Fujita, M., Krugman, P. R., \& Venables, A. J. (2001). The spatial economy: Cities, regions, and international trade. Cambridge, MA/London: MIT Press.

Geyer, H. S. (Ed.). (2006). Global regionalization: Core peripheral trends.

Cheltenham/Northampton: Edward Elgar.

Lang, T., Henn, S., Ehrlich, K., \& Sgibnev, W. (Eds.). (2015). Understanding geographies of polarization and peripheralization: Perspectives from Central and Eastern Europe and beyond. London: Palgrave Macmillan. 